
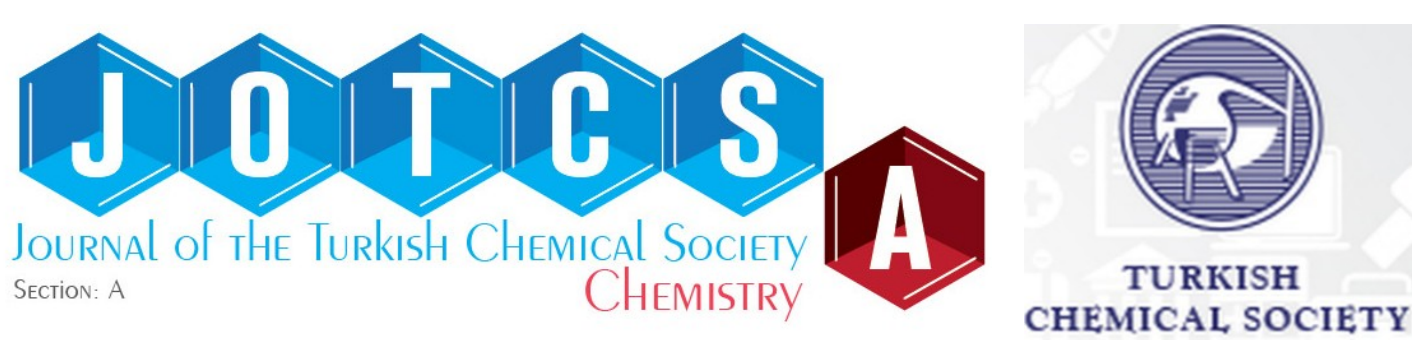

\title{
Reduction of the Structural Iron in Montmorillonite by Electron Transfer from Catechol and its Derivatives
}

\author{
Jasim Hamadi Hassen ${ }^{1 *} \square$, Jack Silver ${ }^{2}$
}

${ }^{1}$ University of Anbar, College of Pharmacy, Department of Pharmaceutical Chemistry, Ramadi, Iraq.

${ }^{2}$ University of Brunel, Wolfson Centre for Material Processing, London, UK.

\begin{abstract}
The structural $\mathrm{Fe}(\mathrm{III})$ in montmorillonite (MMT) clay has been reduced using catechol and its derivatives. It was found that the reduction process is $\mathrm{pH}$-dependent and also depends on the ring substituents. If the catecholic ring has electron-donating substituents, reduction happens at high $\mathrm{pH}$; if the catecholic ring has electron-withdrawing substituents, no reduction occurs. The process involves electron transfer from the hydroxy groups on the compounds to the active site at the iron atoms within the MMT lattice. This site acts as an electron acceptor (Lewis acid). Heat treatment of the reduced sample at $100-300{ }^{\circ} \mathrm{C}$ showed an enhancement of the $\mathrm{Fe}^{2+} / \mathrm{Fe}^{3+}$ ratio, which is attributed to an increase in the proportion of radicalic formation induced by dehydration. The MMT sample was added to the solutions of the catecholic compound and the slurries were stirred for 24 hours in order to reach equilibrium, then filtered, washed, and air-dried. The reactions were monitored using Mössbauer spectroscopy, $x$-ray powder diffraction, differential thermal analysis, electron spin resonance, infrared, and total surface area determination.
\end{abstract}

Keywords: Catechol, montmorillonite, reduction, electron transfer.

Submitted: April 02, 2021. Accepted: October 11, 2021.

Cite this: Hassen JH, Silver J. Reduction of the Structural Iron in Montmorillonite by Electron Transfer from Catechol and its Derivatives. JOTCSA. 2021;8(4):1167-78.

DOI: https://doi.org/10.18596/jotcsa.908713.

*Corresponding author. E-mail: ph.jasimhu@uoanbar.edu.iq, Tel: (009647805845839).

\section{INTRODUCTION}

MMT belongs to the sizeable specific surface area clay minerals with a 2:1 layer structure. An octahedral sheet of alumina surrounded by two layers of tetrahedral silica sheets. There is an access net negative charge that can be balanced by cations like $\mathrm{Na}^{+}, \mathrm{Ca}^{2+}$, and $\mathrm{Mg}^{2+}(1)$. The process of reducing structural iron of MMT and other clays has received significant interest from many researchers due to the wide application of this process in different fields. The iron existence in the clay mineral structure adds to its unique importance. The reason for this is the fact that the oxidation state can be changed and controlled by the influence of external factors. This is in turn, leads to changes in the clay properties. The Fe oxidation state in the crystal lattice of MMT clay has an essential role in determining the surface and colloidal chemistry. It also plays an essential role in the physical behavior of the clay. The valence states of clay's structural iron affect the physicochemical properties such as cation exchange capacity and surface area (2-4). Bacterial reduction of $\mathrm{Fe}$-bearing clay has the ability to change the structure of the clay and causes a decrease in the surface area and an increase in the cation exchange capacity. The process is mainly reversible (5-7). A reduced nontronite clay has shown a noticeable antibacterial activity at $\mathrm{pH} 6$ toward E. coli (8). It was found that $D$. vulgaris is able to reduce structural Fe(III) in four types of clay minerals (9). Humic acid can effectively stimulate the bioreduction rate of structural Fe(III) in clays (10). The $\mathrm{Fe}(\mathrm{II})$ in MMT was found to reduce 2nitrophenol after adsorption (11). The reactivity of structural and surface-bonded Fe(II) in chemically reduced and oxidized nontronite and reduced MMT was investigated using two acetylnitrobenzene 
isomers as a probe (12). An experiment was conducted to investigate the mechanism of Se sorption on MMT clay in deep geological environments under reducing conditions. The Se element was dissolved as selenide (Se(-II)) anions. It was shown by X-ray absorption that the Se-sorbed oxidation state was (0), which implies that Se was oxidized on MMT (13). Mössbauer spectroscopy study showed that $\mathrm{Fe}(\mathrm{II})$ reduces a large amount of $\mathrm{Fe}$ (III) in a low-Fe MMT. The reduction rate extends from 12 to $78 \%$ through a $\mathrm{pH}$ range of $4.0-7.5$. It was suggested that extensive reduction occurs by electron transfer through the basal plane (14). The oxidant production that was produced after oxygenation of reduced nontronite was studied in the presence of four different compounds. The compounds were phosphate, tripolyphosphate, nitrilotriacetic acid, and diaminetetraacetic acid. All the compounds increase the oxidant yields, but the mechanisms vary, depending on the compound type (15). Electron transfer mechanism was suggested in a study concerning $\mathrm{Fe}(\mathrm{II})$-goethite systems $(16,17)$. On the other hand, Fe-bearing clay minerals were used for the reduction of hexavalent chromium. The process is affected by different environmental factors (18-21). Several studies have demonstrated the adsorption of phenol, substituted phenols catechol, and its derivatives on clay minerals (22-26). The structural Fe(II) of MMT can be reduced to $\mathrm{Fe}$ (III) at high $\mathrm{pH}$ if the phenolic ring has an electron donating substituent. The adsorption process includes transferring an electron from the hydroxyl group to the Fe atoms inside the lattice (27). The aim of the current research is to understand how catechols attack and reduce MMT's structural iron, using different analytical tool. The information collected from different analytical tools may help in understanding how the reduction process occurs and how the oxidation state of iron changes.

\section{MATERIALS AND METHODS}

The MMT sample was obtained from Podmore and Sons Ltd. All the chemicals used in this research were of analytical grade obtained from SigmaAldrich Company. Mössbauer spectra were recorded at $77^{\circ} \mathrm{K}$ on a Canberra Multichannel Analyzer using ${ }^{57} \mathrm{Co}$ as a source. The source used was $25 \mathrm{mCi}$ cobalt-57 in a rhodium matrix obtained from the Radiochemical Centre, Amersham. X-ray diffraction patterns were recorded on a Philips diffractometer using CuKa radiation. The differential thermal analysis curves were recorded on a DUPONT 900 Differential Thermal Analyzer. The ESR spectra were recorded on a Varian EI04A X-band spectrometer. The infrared spectra were recorded on a Perkin Elmer 1330 infra-red spectrophotometer. The surface area of the samples was measured by the methods described by other researchers (28). The $\mathrm{pH}$ was monitored using a Philips (PW-91109) digital $\mathrm{pH}$ meter.

\section{MMT- Catecholic Compounds Reaction}

The catecholic compound (100 mg) was added to 1 $\mathrm{g}$ of the MMT clay sample dispersed in $50 \mathrm{~mL}$ distilled water. The $\mathrm{pH}$ was adjusted to 1,7 , and 10.5 and monitored periodically in the first few hours using $0.1 \mathrm{~N} \mathrm{NaOH}$ and $0.1 \mathrm{~N} \mathrm{HCl}$. The mixtures were stirred for 24 hours to reach equilibrium, then filtered, washed, and air-dried.

\section{RESULTS AND DISCUSSION}

When catecholic molecules or their derivatives are brought together with the MMT clay in solution at a $\mathrm{pH}$ high enough to dissociate one or both protons, electron transfer occurs from the catecholic compound to the active sites of the MMT clay. These sites are aluminum exposed at the edges and/or transition metal cations in a high valency state at the planar surface. Our concern is the latter site. Both sites act as electron acceptors, and any initial reduction occurs at the surface; it can propagate into the planar sites by electron diffusion or hopping (29). The organic molecules may approach the pyramidal edges of the MMT, and electron diffusion takes place within the octahedral layers since the organic compounds are expected to be negatively charged at high $\mathrm{pH}$ (Figure 1). When the reduction process is done, there will be a charge imbalance, which may be maintained by the protonation of the adjacent $\mathrm{OH}$ group (30).

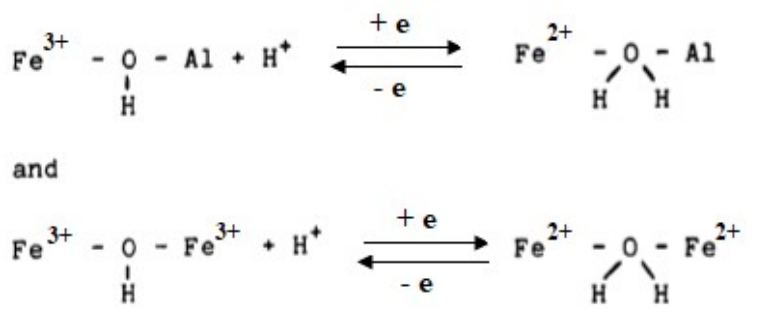

Figure 1: The electron transfer process.

The protons in the equations are derived from molecules of water dissociated in the interlayer space. These protons penetrate the structure by proton tunneling. The resulting $\mathrm{OH}$ - ions in the spaces can pick up $\mathrm{H}^{+}$from the solution outside the proton pump process. At high $\mathrm{pH}$, small amounts of iron, and some other ions, are expected to be extracted from the MMT structure and present in the solution as hydroxides. These hydroxides interact with the catecholic molecules to form iron-catechol complexes:

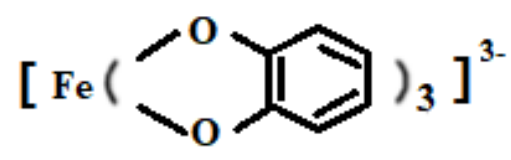

Figure 2: Structure of the iron-catechol complex. 
The mechanism of the MMT structural iron reduction by the catecholic compounds can be described as in Figure 3.

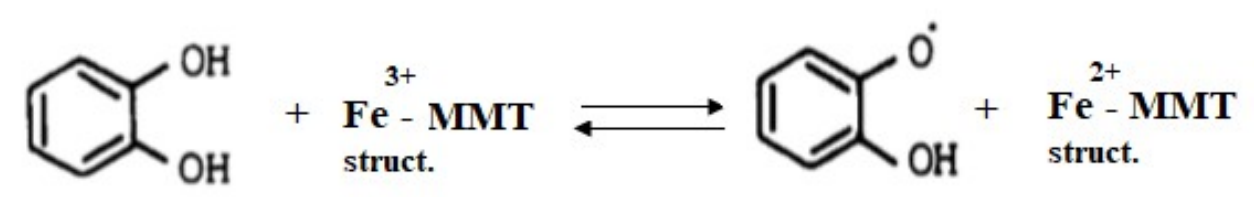

Figure 3: Mechanism of the MMT structural iron reduction by the catecholic compounds.

The radical produced in the last equation undergoes further oxidation to a quinone. For osubstituted compounds like catechol, the expected compound is o-benzoquinone (31).

\section{Mössbauer Spectroscopy}

Mössbauer spectra of MMT-catechol

The Mössbauer spectra of the MMT sample reacted with catechol at $\mathrm{pH} 1$ and 7 showed the same behavior as that of the original sample at the same $\mathrm{pH}$; no effect was seen in the presence of catechol; in fact, some of the iron(II) was oxidized to iron(III), presumably indirectly by oxygen contamination in the solution. The sample reacted with catechol at $\mathrm{pH} 10.5$ shows a considerable enhancement of iron(II) at the expense of the iron(III) content. The $\mathrm{Fe}^{2+} / \mathrm{Fe}^{3+}$ ratio derived from the Mössbauer spectrum was 2.4[5]. The parameter is presented in Table 1 , and Figure 4 shows the spectra at $77 \mathrm{~K}$ of MMT sample reacted with catechol at $\mathrm{pH} 1,7$, and 10.5 .

Table 1: The ${ }^{57} \mathrm{Fe}$ Mössbauer parameters at $77^{\circ} \mathrm{K}$ of the original MMT sample and the sample reacted with catechol at different $\mathrm{pH}^{\prime}$ s in an aqueous solution. Data were collected on the dried solids.

\begin{tabular}{|c|c|c|c|c|c|c|}
\hline Sample & $\mathbf{p H}$ & $\delta \mathrm{mms}^{-1}$ & $\Delta \mathrm{mms}^{-1}$ & $\Gamma \mathrm{mms}^{-1}$ & $\begin{array}{c}\text { Absorption } \\
\text { area } \%\end{array}$ & $\begin{array}{c}\mathrm{Fe}^{2+} / \mathrm{Fe}^{3+} \\
\text { ratio }\end{array}$ \\
\hline Original MMT & - & $\begin{array}{l}0.43[2] \\
1.25[1]\end{array}$ & $\begin{array}{l}0.65[2] \\
3.03[1]\end{array}$ & $\begin{array}{l}0.30[2] \\
0.14[1]\end{array}$ & $\begin{array}{l}51[4] \\
49[3]\end{array}$ & $1[2]$ \\
\hline MMT-catechol & 1 & $0.43[1]$ & $0.64[1]$ & $0.31[1]$ & 100 & - \\
\hline$=$ & 7 & $\begin{array}{l}0.39[1] \\
1.48[2]\end{array}$ & $\begin{array}{l}0.79[1] \\
2.56[4]\end{array}$ & $\begin{array}{l}0.40[2] \\
0.24[3]\end{array}$ & $\begin{array}{l}78[3] \\
22[4]\end{array}$ & $0.3[1]$ \\
\hline$=$ & 10.5 & $\begin{array}{l}0.49[2] \\
1.27[1]\end{array}$ & $\begin{array}{l}0.73[4] \\
3.04[1]\end{array}$ & $\begin{array}{l}0.26[3] \\
0.12[1]\end{array}$ & $\begin{array}{l}30[5] \\
70[4]\end{array}$ & $2.4[5]$ \\
\hline
\end{tabular}

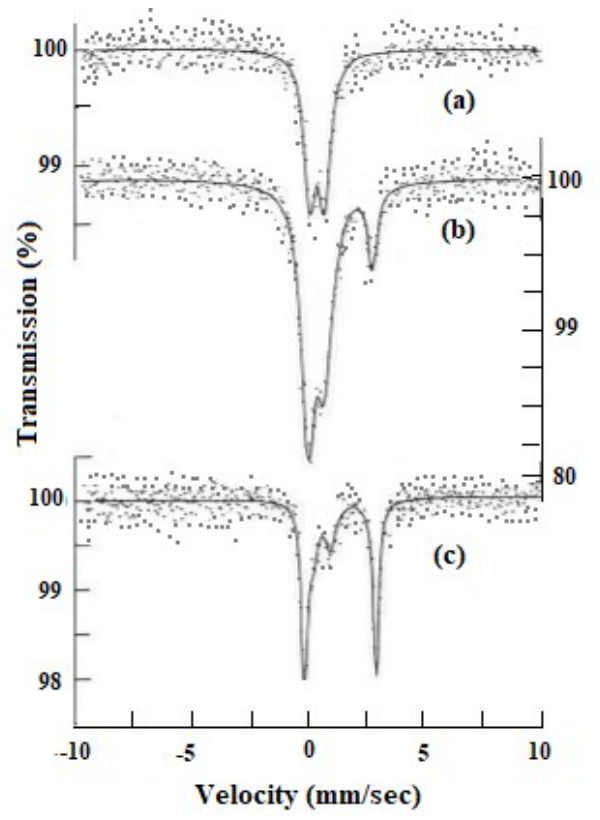

Figure 4: The ${ }^{57} \mathrm{Fe}$ Mössbauer spectra at $77^{\circ} \mathrm{K}$ of $\mathrm{MMT}$ reacted with catechol at (a) $\mathrm{pH} 1,(\mathrm{~b}) \mathrm{pH} 7,(\mathrm{c}) \mathrm{pH}$ 10.5 . 
methycatechol, and two compounds with electronwithdrawing substituents, 4-nitrocectechol and tetrabromocatechol were reacted with the MMT sample at $\mathrm{pH}$ 10.5. The Mössbauer parameters are listed in Table 2, and the spectra of these samples are shown in Figure 5.

Table 2: The ${ }^{57} \mathrm{Fe}$ Mössbauer parameters at $77^{\circ} \mathrm{K}$ of the MMT samples reacted with different substituted catechol at $\mathrm{pH} 10.5$ in an aqueous solution. Data were collected on the dried solids.

\begin{tabular}{|c|c|c|c|c|c|}
\hline Samples & $\delta \mathrm{mms}^{-1}$ & $\Delta \mathrm{mms}^{-1}$ & $\Gamma \mathrm{mms}^{-1}$ & $\begin{array}{c}\text { Absorption } \\
\text { area } \%\end{array}$ & $\begin{array}{c}\mathrm{Fe}^{2+} / \mathrm{Fe}^{3+} \\
\text { ratio }\end{array}$ \\
\hline MMT-4-tert- butylcatechol & $\begin{array}{l}0.42[2] \\
1.26[1]\end{array}$ & $\begin{array}{l}0.74[2] \\
3.04[1]\end{array}$ & $\begin{array}{l}0.30[2] \\
0.20[1]\end{array}$ & $\begin{array}{l}30[3] \\
70[2]\end{array}$ & $2.4[3]$ \\
\hline MMT-4-methylcatechol & $\begin{array}{l}0.44[3] \\
1.23(1]\end{array}$ & $\begin{array}{l}0.76[3] \\
3.02[1]\end{array}$ & $\begin{array}{l}0.30[3] \\
0.14[1]\end{array}$ & $\begin{array}{l}29[4] \\
71[3]\end{array}$ & $2.4[3]$ \\
\hline MMT-4-nitrocatechol & $\begin{array}{l}0.44[1] \\
1.26[1]\end{array}$ & $\begin{array}{l}0.67[2] \\
3.04[1]\end{array}$ & $\begin{array}{l}0.28[2] \\
0.16[1]\end{array}$ & $\begin{array}{l}46[3] \\
54[3]\end{array}$ & $1.2[2]$ \\
\hline MMT-tetrabromocatechol & $\begin{array}{l}0.31[1] \\
1.47[1]\end{array}$ & $\begin{array}{l}0.82[3] \\
2.60[2]\end{array}$ & $\begin{array}{l}0.41[2] \\
0.17[2]\end{array}$ & $\begin{array}{l}78[6] \\
22[3]\end{array}$ & $0.3[1]$ \\
\hline
\end{tabular}

The samples reacted with 4-tert-butylcatechol and 4-methylcatechol showed a clear reduction. While little or no reduction is observed in the sample reacted with 4-nitrocatechol and tetrabromocatechol compounds. The 4-nitro and tetrabromo are withdrawing substituents and tend to withdraw electron density from the catecholic ring. The electron can be considered to reside on the substituent, leaving the molecule unable to transfer an electron to active sites on MMT. Electron-donating substituents, such as 4-tertbutyl and 4-methyl, facilitate electron transfer from the ring to the clay.

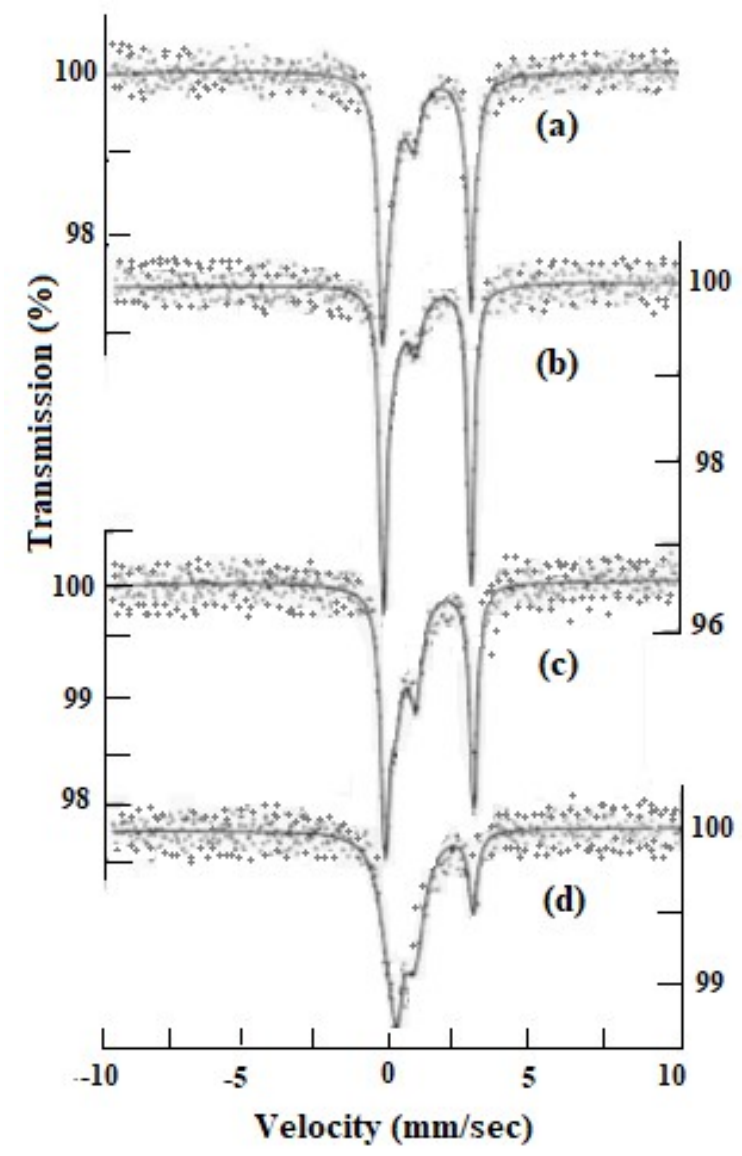

Figure 5: The ${ }^{57} \mathrm{Fe}$ Mössbauer spectra at $77^{\circ} \mathrm{K}$ of MMT reacted at $\mathrm{pH} 10.5$ with (a) 4-tert-butylcatechol, (b) 4-methylcatechol, (c) 4-nitrocatechol, (d) tetrabromocatechol. Mössbauer spectra of the fired MMT-catechol
sample
In order to investigate the effect of firing on the powdered catechol-reduced MMT, the sample was subjected to a firing treatment ranging from 100 to 
$800{ }^{\circ} \mathrm{C}$ for a period of 10 minutes under air (Figure $6)$. As the firing temperature increased, the quadrupole splitting of the $\mathrm{Fe}^{3+}$ doublet shows a very small increase which indicates a mild distortion of the lattice. The linewidth of the $\mathrm{Fe}^{2+}$ peak became very narrow $\left(\Gamma=0.15 \mathrm{mms}^{-1}\right)$, which indicates a unique type of coordination. Oxidation of the $\mathrm{Fe}^{2+}$ ions by firing occurred at higher temperatures than the original MMT sample. The $\mathrm{Fe}^{2+}$ doublet disappeared at $300{ }^{\circ} \mathrm{C}$ in the original sample, while its appearance continued to $600^{\circ} \mathrm{C}$ in the MMT-catechol sample. The amount of $\mathrm{Fe}^{2+}$ increased with increasing the firing temperature from $100-300{ }^{\circ} \mathrm{C}$ and then decreasing with firing to a higher temperature as shown in the $\mathrm{Fe}^{2+} / \mathrm{Fe}^{3+}$ ration in Table 3 . Other researchers noticed the reduction enhancement upon firing during the reaction between phenol and MMT (32). They attributed this to an enhancement of radical species induced by dehydration. The transferring of the electrons from the organic compounds to the active site of the $\mathrm{Fe}^{3+}$ may be facilitated by firing (Table 3).
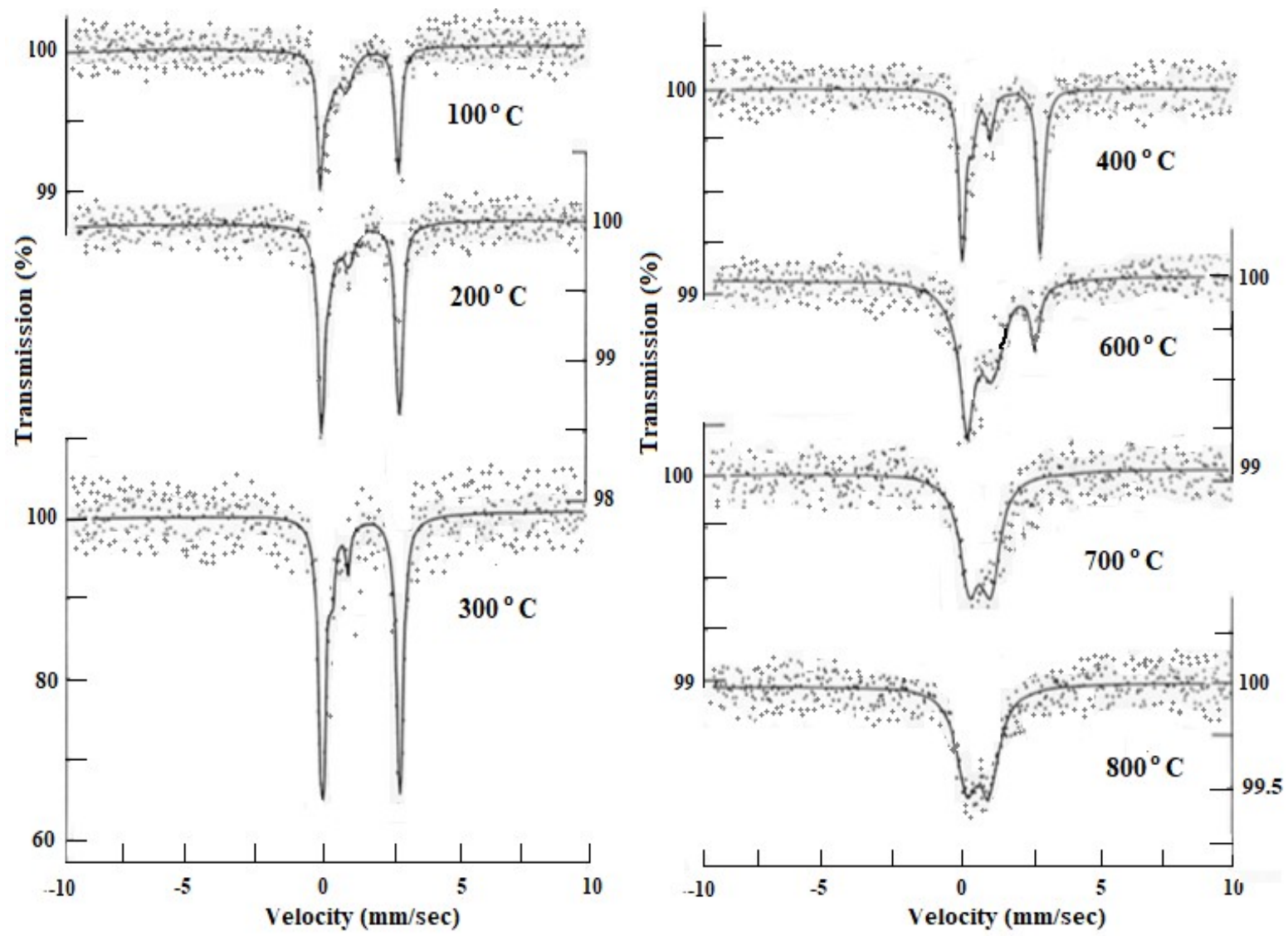

Figure 6: The ${ }^{57} \mathrm{Fe}$ Mössbauer at $77 \mathrm{~K}$ of $\mathrm{MMT}$-catechol samples reacted at $\mathrm{pH} 10.5$ and fired in the air at various temperatures for 10 minutes. The temperature of firing is indicated.

Table 3: The ${ }^{57} \mathrm{Fe}$ Mössbauer parameters at $77 \mathrm{~K}$ of the fired MMT-catecholic sample.

\begin{tabular}{|c|c|c|c|c|c|}
\hline Temp. & $\delta \mathrm{mms}^{-1}$ & $\Delta \mathrm{mms}^{-1}$ & $\Gamma \mathrm{mms}^{-1}$ & $\begin{array}{c}\text { Absorption } \\
\text { Area } \%\end{array}$ & $\begin{array}{c}\mathrm{Fe}^{2+} / \mathrm{Fe}^{3+} \\
\text { ratio }\end{array}$ \\
\hline \multirow[t]{2}{*}{$100^{\circ} \mathrm{C}$} & $0.43[4]$ & $0.65[5]$ & $0.31[5]$ & $39[8]$ & $1.6[4]$ \\
\hline & $1.26[1]$ & $3.06[1]$ & $0.14[1]$ & $61[5]$ & \\
\hline \multirow[t]{2}{*}{$200^{\circ} \mathrm{C}$} & $0.44[3]$ & $0.73[5]$ & $0.27[4]$ & $24[5]$ & $3.3[9]$ \\
\hline & $1.26[1]$ & $3.03[1]$ & $0.16[1]$ & $76[4]$ & \\
\hline \multirow[t]{2}{*}{$300^{\circ} \mathrm{C}$} & $0.46[4]$ & $0.57[6]$ & $0.12[5]$ & $11[7]$ & $14.3[9]$ \\
\hline & $1.27[1]$ & $3.03[1]$ & $0.16[1]$ & $89[8]$ & \\
\hline \multirow[t]{2}{*}{$400^{\circ} \mathrm{C}$} & $0.48[1]$ & $0.67[5]$ & $0.15[4]$ & $22[8]$ & $4.2[1]$ \\
\hline & $1.25[1]$ & $3.02[1]$ & $0.15[1]$ & $78[8]$ & \\
\hline \multirow[t]{2}{*}{$600^{\circ} \mathrm{C}$} & $0.41[3]$ & $0.96[5]$ & $0.53[5]$ & $21[7]$ & $4.3[1]$ \\
\hline & $1.21[2]$ & $2.64[4]$ & $0.20[3]$ & $79[9]$ & \\
\hline $700{ }^{\circ} \mathrm{C}$ & $0.36[2]$ & $0.80[4]$ & $0.44[4]$ & 100 & - \\
\hline $800^{\circ} \mathrm{C}$ & $0.31[2]$ & $0.47[4]$ & $0.47[4]$ & 100 & - \\
\hline
\end{tabular}




\section{X-Ray Powder Diffraction (XRD)}

The basal spacing of the air-dried MMT sample is $13 \AA$ increasing to $17 \AA$ on ethylene glycol treatment. When this sample heated at $120{ }^{\circ} \mathrm{C}$ for two hours, it showed partial collapse with a basal spacing of $12.62 \AA$. The collapse was completed on heating at $375^{\circ} \mathrm{C}$ for 1 hour (Figure 7). MMT gives a basal spacing of $9.6 \AA$ when no molecules are between the unit layers. The MMT sample that reacted with the catecholic compounds at $\mathrm{pH} 10.5$ did not show the $13 \AA$ basal spacing of the original sample, possibly due to the presence of sodium ions from the $\mathrm{NaOH}$ used to adjust the $\mathrm{pH}$. The sample containing the organics did not show the $17 \AA$ basal spacing on treatment with ethylene glycol again, which suggests that the ligands are present on the MMT crystal edges. These then cause blocking of some of the layers and prevent the complete swelling of ethylene glycol. In addition to this, the XRD pattern peaks obtained are slightly asymmetrical in the air-dried samples, which suggests a mixed-layer sequence (Table 4).

From the results listed in Table 4, there is no evidence for the intercalation of the catecholic compounds into the MMT interlayer. Therefore, an experiment was carried out to open the MMT lattice by dispersing $1 \mathrm{~g}$ of the MMT in a $50 \mathrm{~mL}$ solution of $\mathrm{NaCl}$ in water, as the sodium ions are able to open the interlayer to about $20 \AA$ in water. The sample was allowed to stir for 1 hour, and then $100 \mathrm{mg}$ of catechol was added, and the mixture was stirred for a further 24 hours. Upon examination, the sample showed no indications of intercalation. The sample gave basal spacing of $12.3,16.67,12.45$, and $11.78 \AA$ for the air-dried, ethylene glycol treated, $120^{\circ} \mathrm{C}$ heated, and $300{ }^{\circ} \mathrm{C}$ heated samples, respectively. At low $\mathrm{pH}$, where no sodium ions are present, the basal spacing of the catechol-MMT sample was $13 \AA$, but the ethylene glycol treated sample did not swell to $17 \AA$, which provides further evidence for these compounds affecting the interlayer swelling. Figure 8 shows the XRD patterns of the air-dried MMT-catechol samples reacted at $\mathrm{pH} 1,7$, and 10.5 .

\section{Differential Thermal Analysis, DTA}

DTA analysis showed that the curves of the original MMT sample subjected to $\mathrm{pH}$ 's of 1,7 , and 10.5 are similar to the curve of the original sample. The change in $\mathrm{pH}$ does not affect the curve. When the MMT was reacted with the organic compounds, only the curves of the sample reacted at $\mathrm{pH} 10.5$ were extensively modified (Figure 9). Catechol has two endothermic peaks at 100 and $200{ }^{\circ} \mathrm{C}$ (33), which do not appear on the curve of an MMT sample reacted with catechol, probably due to complexation with MMT. The main alteration in the curves of the sample reacted at $\mathrm{pH} 10.5$ may be due to the formation of metal-ligand complexes adsorbed onto the clay surface since some cations such as iron are solubilized by catechol and expected to be found in the solution at high $\mathrm{pH}$. Such complexes are associated with water molecules, which can be driven off as endothermic peaks before the first endothermic reaction of the MMT occurs.

Table 4: The basal spacing of some MMT-compounds.

\begin{tabular}{|c|c|c|c|c|}
\hline \multirow[b]{2}{*}{ Samples } & \multicolumn{4}{|c|}{ 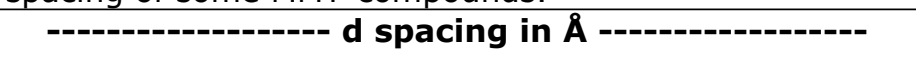 } \\
\hline & Air-dried & EG & $\begin{array}{l}\text { Heated at } \\
120^{\circ} \mathrm{C} 2 \mathrm{~h} .\end{array}$ & $\begin{array}{l}\text { Heated at } \\
375^{\circ} \mathrm{C} 1 \mathrm{~h} .\end{array}$ \\
\hline MMT & 13 & 17 & 12.62 & 9.6 \\
\hline MMT-catechol pH 10.5 & 12.8 & 16.67 & 12.27 & 10.04 \\
\hline MMT-4-tert-butylcatechol pH 10.5 & 12.45 & 16.67 & 13.3 & 10.28 \\
\hline MMT-4-methylcatechol pH 10.5 & 12.27 & 16.67 & 12.81 & 9.71 \\
\hline MMT-4-nitrocatechol pH 10.5 & 12.27 & 16.67 & 13 & 9.71 \\
\hline MMT-tetrabromocatechol pH 10.5 & 11.94 & 16.67 & 13 & 9.71 \\
\hline
\end{tabular}




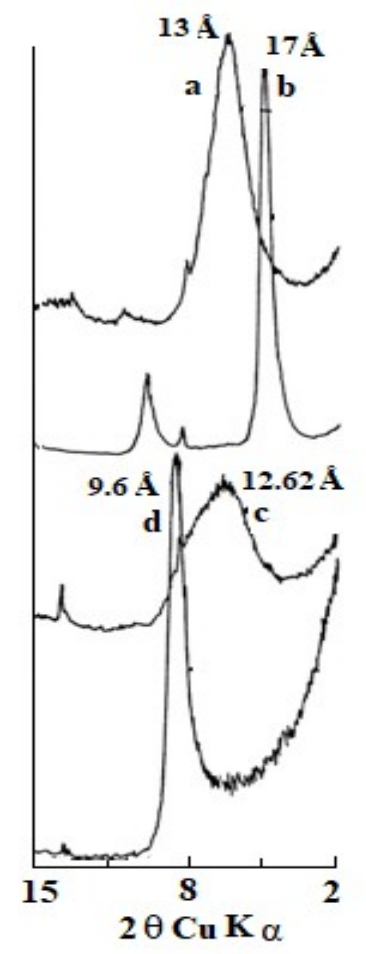

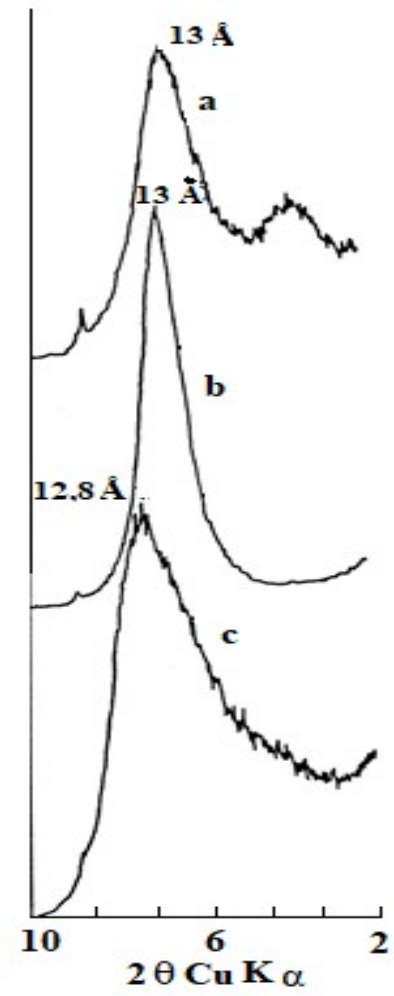

Figure 7: X-ray powder diffraction patterns of MMT Figure 8: X-ray powder diffraction patterns of MMT-

(a) untreated sample, (b) treated with EG, (c) heated at $120^{\circ} \mathrm{C}$, (d) $375^{\circ} \mathrm{C}$.

\section{Electron Spin Resonance (ESR)}

Silicon, aluminum, magnesium and alkali, and alkaline earth metals are the most abundant ions usually found in clays that are diamagnetic. Paramagnetic ions such as $\mathrm{Fe}^{3+}$ may be found substituted for silicon, aluminum, or magnesium. The spectrum of the original sample is characterized by features with g-values of 2.0, 2.2, $3.7,4.3$, and 9.6, similar to the result reported by other workers (34). The ESR features with gvalues of $3.7,4.3$, and 9.6 have been assigned to $\mathrm{Fe}^{3+}$ in a site of near rhombic symmetry, while the other features arise from $\mathrm{Fe}^{3+}$ in a different type of environment (Figure 10).

The sample of catechol-reduced MMT exhibits substantial changes in the main features of the spectra. The 2.2 and $9.6 \mathrm{~g}$-value signals are broader than those found in the untreated sample. The $3.7 \mathrm{~g}$-value signals disappeared from the spectra, and that with a g-value of 4.3 was narrower and less intense than in the untreated sample. The reduction of MMT with catechol caused a reduction in the intensities of the signals, which can be assigned to the structural $\mathrm{Fe}^{3+}$. This result catechol sample reacted at (a) $\mathrm{pH} 1$, (b) $\mathrm{pH} 7$, (c) $\mathrm{pH} 10.5$.

is in good agreement with the Mössbauer data, which revealed an incomplete reduction of the structural $\mathrm{Fe}^{3+}$. An enhancement in the $\mathrm{g}=2.0$ signal was observed due to the formation of a radical. This signal is similar to those reported by other workers (35) obtained from the reaction of some aromatic molecules with clays. The reaction of the hydroxybenzene compounds with the MMT involves a radical formation in the first stage, which oxidized to a quinone at a later stage. From the ESR results, it appears that part of these compounds remains in the radical (semiquinone) form on the MMT surface. These radicals are responsible for the signal at $\mathrm{g}=2.0$.

Similar behavior in the ESR spectra was observed for the MMT samples reduced by 4-methyl and 4tert-butylcatechol, which have electron-donating ability (Figure 10 ). The $\mathrm{g}=2.0$ signal was greatly enhanced in the sample reduced with 4-tertbutylcatechol. However, there were some remnants of the signal at $\mathrm{g}=3.7$. Reaction with the 4-nitro and tetrabromo substituents also showed an enhancement of the signal $\mathrm{g}=2.0$, and the $\mathrm{g}=2.2$ signal became broader. 


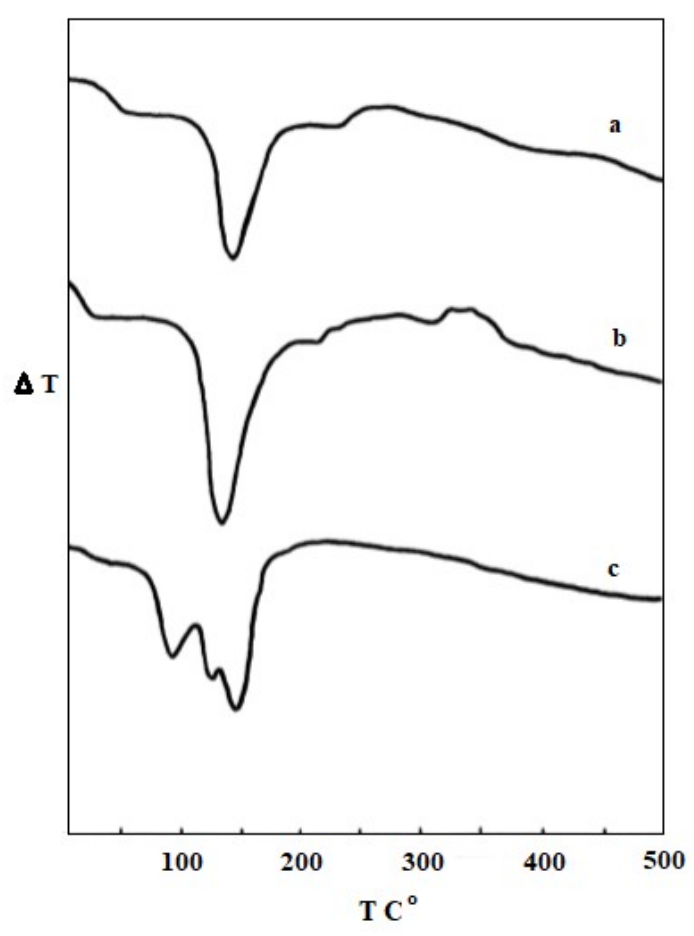

Figure 9: DTA curves of MMT reacted with catechol Figure 10: ESR spectra at room temperature of (a) at (a) $\mathrm{pH} 1$, (b) $\mathrm{pH} 7$, (c) $\mathrm{pH} 10.5$.

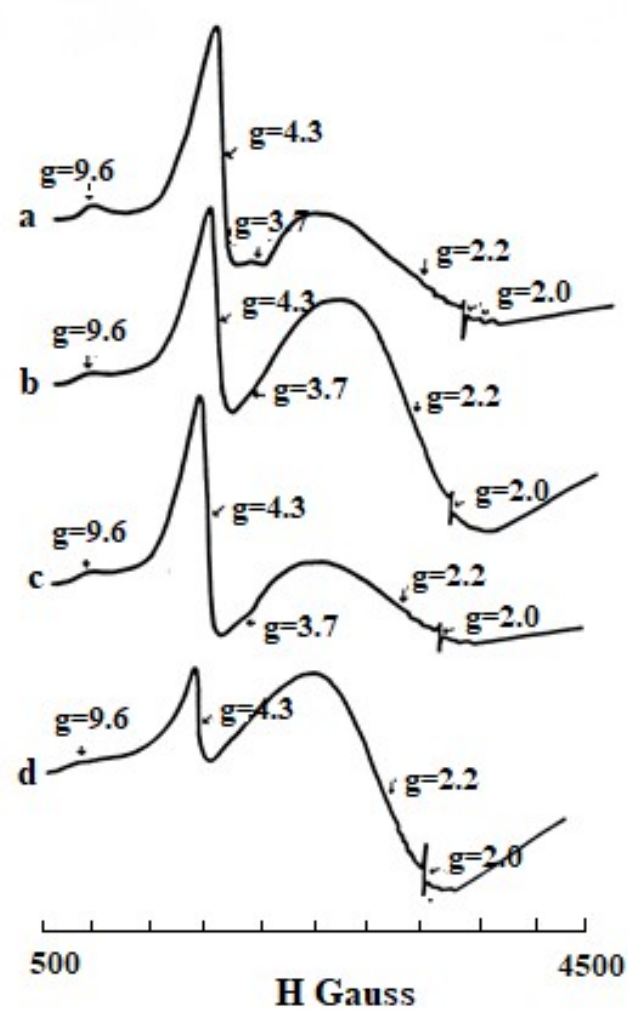

MMT, MMT reacted with catechol at (b) $\mathrm{pH} \mathrm{1,} \mathrm{(c)} \mathrm{pH}$ 7, (d) $\mathrm{pH} 10.5$.

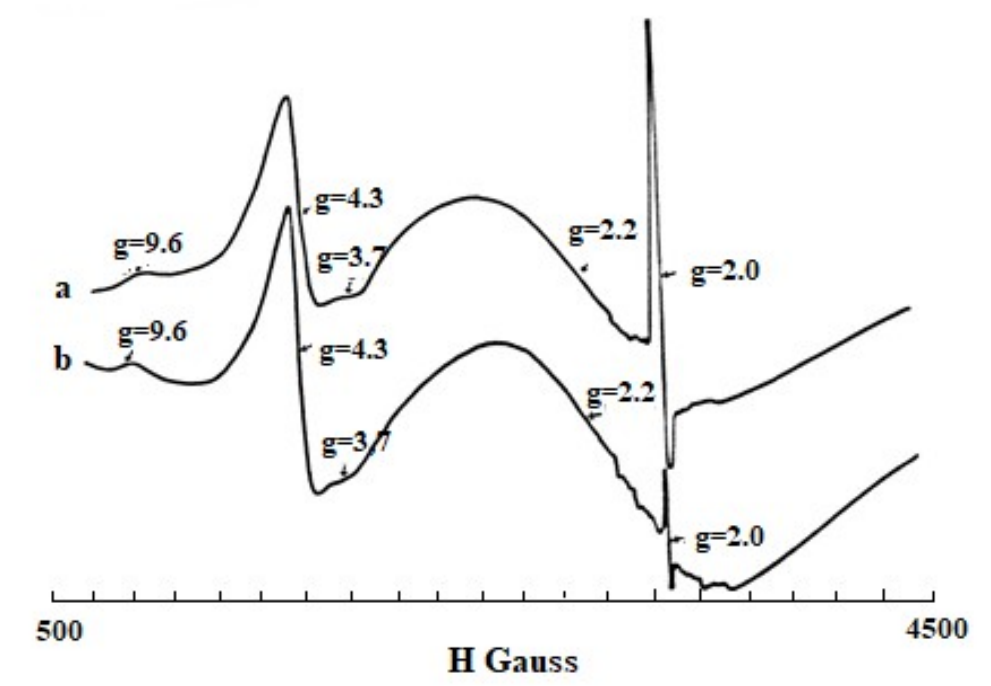

Figure 10: ESR spectra at room temperature of MMT reacted at $\mathrm{pH} 10.5$ with (a) 4-tert-butylchatechol, (b) 4-methylcatechol.

\section{Infra-Red Spectra (IR)}

The MMT's main features in the IR region are the $\mathrm{Si}-\mathrm{O}$ stretching and $\mathrm{OH}$ bending. The position of these bands are at 800,850, 880, 917, and 1040 $\mathrm{cm}^{-1}$ and are assigned to $\mathrm{Fe}^{3+}-\mathrm{OH}-\mathrm{Fe}^{3+}, \mathrm{Al}-\mathrm{OH}-\mathrm{Mg}$, $\mathrm{Fe}^{3+}-\mathrm{OH}-\mathrm{Al}, \mathrm{Al}-\mathrm{OH}-\mathrm{Al}$, and $\mathrm{Si}-\mathrm{O}$, respectively $(36,37)$ (Table 5). The IR spectrum also exhibits bands due to the adsorbed compounds on the MMT, but we will discuss only the effect of these compounds on the prominent montmorillonite bands. The sharpness and position of $\mathrm{OH}$ bending modes of the sample reacted with different compounds varies from one compound to another.

The Si-O stretching band at $1040 \mathrm{~cm}^{-1}$ and the $\mathrm{Fe}^{3+}-\mathrm{OH}-\mathrm{Al}$ band at $880 \mathrm{~cm}^{-1}$ disappeared in most of the samples. The disappearance of the latter band is noticeable in the reduced samples. This band disappeared in MMT and nontronite samples reduced with hydrazine and dithionite, and its 
disappearance was attributed to the protonation of the adjacent $\mathrm{OH}$ group (30). The band at $800 \mathrm{~cm}^{-1}$ in the catechol reduced MMT sample, which is assigned to $\mathrm{Fe}^{3+}-\mathrm{OH}-\mathrm{Fe}^{3+}$ bending, is shifted to 790 $\mathrm{cm}^{-1}$. This shift has also been found in some other samples. The band at $850 \mathrm{~cm}^{-1}$, which is assigned to $\mathrm{Al}-\mathrm{OH}-\mathrm{Mg}$ bending, is shifted to $838 \mathrm{~cm}^{-1}$. Both bands are enhanced upon reduction with catechol. The $880 \mathrm{~cm}^{-1}$ band disappeared from the catechol reduced sample and also from the substituted catechol reduced samples, 4-methyl and 4-tertbutyl catechol.

\section{Total Surface Area Determination}

The total surface area is a fundamental property of clays. It can be determined by the retention of ethylene glycol (EG). MMT clay can take two layers of EG molecules between the interlayer spacing. The resultant areas were calculated using Dyal and Hendricks (38) value of $810 \mathrm{~m}^{2} / \mathrm{g}$ for the total surface area of MMT. The original MMT sample gave a value of $839 \mathrm{~m}^{2} / \mathrm{g}$ (Table 6). This value was decreased by about $100 \mathrm{~m}^{2} / \mathrm{g}$ in the sample reacted with the compounds at $\mathrm{pH} 10.5$, which is attributed to the presence of these compounds on the crystal edges of MMT causes blocking of some layers, preventing complete swelling. No apparent decrease in the values was found in the sample reacted at $\mathrm{pH} 1$ and 7 . The possibility of the presence of the organic compounds on the crystal edges at $\mathrm{pH} 10.5$ seems greater than at $\mathrm{pH} 1$ and 7. This may be due to the formation of complexes of these compounds and cations that are liberated at high $\mathrm{pH}$. These complexes increase the possibility of blocking the layers.

\section{CONCLUSIONS}

Catecholic compounds containing electrondonating substituents have the ability to reduce the structural iron of MMT at high $\mathrm{pH}$. The process depends on the $\mathrm{pH}$, ring substituents and conjugation. No reduction occurs if the catecholic ring has electron-withdrawing substituents. The process involves electron transfer from the hydroxy groups on the compounds to the active site at the iron atoms within the MMT lattice. The reduction process can be enhanced by heating the powdered sample up to $300{ }^{\circ} \mathrm{C}$. The $\mathrm{Fe}^{2+} / \mathrm{Fe}^{3+}$ ratio increases due to the increase in the proportion of radical formation induced by dehydration.

Table 5: Selected features of the infra-red spectra $\left(\mathrm{cm}^{-1}\right)$ of the MMT sample reacted with the catecholic compounds.

\begin{tabular}{|c|c|c|c|c|c|c|}
\hline Sample & $\mathbf{p H}$ & Si-O & $\begin{array}{c}\text { Al-OH- } \\
\text { Al }\end{array}$ & $\begin{array}{c}\mathrm{Fe}^{3+}-\mathrm{OH}- \\
\mathrm{Al}\end{array}$ & $\begin{array}{c}\text { Al-OH- } \\
\text { Mg }\end{array}$ & $\begin{array}{c}\mathrm{Fe}^{3+}-\mathrm{OH}- \\
\mathrm{Fe}^{3+}\end{array}$ \\
\hline MMT & - & $1050 \mathrm{sh}$ & 917 w & $880 w$ & $850 \mathrm{~m}$ & $800 \mathrm{~s}$ \\
\hline MMT-catechol & 10.5 & - & $915 \mathrm{sh}$ & - & $838 \mathrm{~s}$ & $790 \mathrm{~s}$ \\
\hline MMT-4-nitrocatechol & $=$ & - & 915 w & $890 \mathrm{sh}$ & $848 \mathrm{~m}$ & $800 \mathrm{~m}$ \\
\hline MMT-tetrabromocatechol & $=$ & $1015 \mathrm{sh}$ & 918 w & $885 \mathrm{sh}$ & $835 \mathrm{~m}$ & $795 \mathrm{~s}$ \\
\hline MMT-4-methylcatechol & $=$ & - & $915 \mathrm{~m}$ & - & $845 \mathrm{~m}$ & $800 \mathrm{~m}$ \\
\hline MMT-4-tert-butylcatechol & $=$ & - & $913 \mathrm{~s}$ & - & $840 \mathrm{~m}$ & $795 \mathrm{~s}$ \\
\hline
\end{tabular}

Table 6: The total surface areas of the samples.

\begin{tabular}{ccc}
\hline Samples & $\mathbf{p H}$ & $\begin{array}{c}\text { Total surface } \\
\text { area in } \mathbf{~ m}^{\mathbf{2} / \mathbf{g}}\end{array}$ \\
\hline MMT & - & 839 \\
MMT-catechol & 10.5 & 710 \\
MMT-4-methylcatechol & 10.5 & 629 \\
MMT-4-tert-butylcatechol & 10.5 & 634 \\
MMT-4-nitrocatechol & 10.5 & 641 \\
MMT-tetrabromocatechol & 10.5 & 622
\end{tabular}

\section{REFERENCES}

1. Ziemiański $P$, Kałahurska $K$, Samojeden B. Selective catalytic reduction of $\mathrm{NO}$ with $\mathrm{NH} 3$ on mixed alumina-iron (III) oxide pillared montmorillonite "Cheto" Arizona, modified with hexamminecobalt (III) chloride. Adsorption Science \& Technology. 2017 Dec;35(9-10):82533. $\leq \mathrm{DOI}>$. 
2. Pentráková L, Su K, Pentrák M, Stucki JW. A review of microbial redox interactions with structural $\mathrm{Fe}$ in clay minerals. Clay miner. 2013 Jun;48(3):543-60. <DOl>.

3. Luan F, Liu Y, Griffin AM, Gorski CA, Burgos WD. Iron(III)-Bearing Clay Minerals Enhance Bioreduction of Nitrobenzene by Shewanella putrefaciens CN32. Environ Sci Technol. 2015 Feb 3;49(3):1418-26. <DOI>.

4. Lee K, Kostka JE, Stucki JW. Comparisons of structural Fe reduction in smectites by bacteria and dithionite: an infrared spectroscopic study. Clays Clay Miner. 2006 Apr 1;54(2):195-208. <DOl>.

5. Perdrial JN, Warr LN, Perdrial N, Lett M-C, Elsass F. Interaction between smectite and bacteria: Implications for bentonite as backfill material in the disposal of nuclear waste. Chemical Geology. 2009 Jun;264(1-4):281-94. <DOI>.

6. Stucki JW, Kostka JE. Microbial reduction of iron in smectite. Comptes Rendus Geoscience. 2006 Jun;338(6-7):468-75. $\leq$ DOI>.

7. Pentráková L, Su K, Pentrák M, Stucki JW. A review of microbial redox interactions with structural Fe in clay minerals. Clay miner. 2013 Jun;48(3):543-60. <DOI>.

8. Wang X, Dong $\mathrm{H}$, Zeng Q, Xia Q, Zhang L, Zhou Z. Reduced Iron-Containing Clay Minerals as Antibacterial Agents. Environ Sci Technol. 2017 Jul 5;51(13):7639-47. <DOI>.

9. Liu D, Dong H, Bishop ME, Zhang J, Wang H, Xie $S$, et al. Microbial reduction of structural iron in interstratified illite-smectite minerals by a sulfatereducing bacterium: Bioreduction of structural iron in clay minerals by a SRB. Geobiology. 2012 Mar;10(2):150-62. $\leq$ DOl $>$.

10. Liu G, Qiu S, Liu B, Pu Y, Gao Z, Wang J, et al. Microbial reduction of $\mathrm{Fe}$ (III)-bearing clay minerals in the presence of humic acids. Sci Rep. 2017 Jun; $7(1): 45354$. $\leq$ DOl $>$.

11. Wu H, Song Z, Lv M, Zhao D, He G. IronPillared Montmorillonite As An Inexpensive Catalyst For 2-Nitrophenol Reduction. Clays Clay Miner. 2018 Oct;66(5):415-25. <DOI>.

12. Hofstetter TB, Neumann A, Schwarzenbach RP. Reduction of Nitroaromatic Compounds by $\mathrm{Fe}$ (II) Species Associated with Iron-Rich Smectites. Environ Sci Technol. 2006 Jan 1;40(1):235-42. $\leq$ DOI $>$.

13. Sugiura $Y$, Tomura $T$, Ishidera $T$, Doi $R$, Francisco PCM, Shiwaku $H$, et al. Sorption behavior of selenide on montmorillonite. J Radioanal Nucl Chem. 2020 May;324(2):615-22. <DOI>.

14. Latta DE, Neumann A, Premaratne WAPJ, Scherer MM. Fe(II)-Fe(III) Electron Transfer in a Clay Mineral with Low Fe Content. ACS Earth Space Chem. 2017 Jun 15;1(4):197-208. <DOl>.

15. Zeng $Q$, Dong $H$, Wang X. Effect of ligands on the production of oxidants from oxygenation of reduced Fe-bearing clay mineral nontronite. Geochimica et Cosmochimica Acta. 2019 Apr;251:136-56. <DOI>.

16. Notini L, Latta DE, Neumann A, Pearce CI, Sassi M, N'Diaye AT, et al. A Closer Look at Fe(II) Passivation of Goethite. ACS Earth Space Chem. 2019 Dec 19;3(12):2717-25. <DOI>.

17. Notini L, Latta DE, Neumann A, Pearce CI, Sassi M, N'Diaye AT, et al. The Role of Defects in $\mathrm{Fe}(\mathrm{II})-G o e t h i t e$ Electron Transfer. Environ Sci Technol. 2018 Mar 6;52(5):2751-9. <DOI>.

18. Joe-Wong C, Brown GE, Maher K. Kinetics and Products of Chromium(VI) Reduction by Iron(II/III)-Bearing Clay Minerals. Environ Sci Technol. 2017 Sep 5;51(17):9817-25. <DOI>.

19. Liu X, Dong $H$, Zeng $Q$, Yang $X$, Zhang D. Synergistic Effects of Reduced Nontronite and Organic Ligands on $\mathrm{Cr}(\mathrm{VI})$ Reduction. Environ Sci Technol. 2019 Dec 3;53(23):13732-41. <DOl>.

20. Liao W, Ye Z, Yuan S, Cai Q, Tong M, Qian A, et al. Effect of Coexisting Fe(III) (oxyhydr)oxides on $\mathrm{Cr}(\mathrm{VI})$ Reduction by $\mathrm{Fe}(\mathrm{II})$-Bearing Clay Minerals. Environ Sci Technol. 2019 Dec 3;53(23):13767-75. <DOI>.

21. Joe-Wong C, Weaver KL, Brown ST, Maher K. Chromium isotope fractionation during reduction of Chromium(VI) by Iron(II/III)-bearing clay minerals. Geochimica et Cosmochimica Acta. 2021 Jan;292:235-53. <DOI>.

22. Carriazo J, Guélou E, Barrault J, Tatibouët JM, Molina $R$, Moreno $S$. Catalytic wet peroxide oxidation of phenol by pillared clays containing $\mathrm{Al}-$ Ce-Fe. Water Research. 2005 Oct;39(16):3891-9. $\leq \mathrm{DOI}>$.

23. Cheng J, Ming Yu S, Zuo P. Horseradish peroxidase immobilized on aluminum-pillared interlayered clay for the catalytic oxidation of phenolic wastewater. Water Research. 2006 Jan;40(2):283-90. <DOI>.

24. Ko CH, Fan C, Chiang PN, Wang MK, Lin KC. pNitrophenol, phenol and aniline sorption by organo-clays. Journal of Hazardous Materials. 2007 Oct; 149(2):275-82. <DOI>. 
25. Shakir K, Ghoneimy HF, Elkafrawy AF, Beheir ShG, Refaat M. Removal of catechol from aqueous solutions by adsorption onto organophilicbentonite. Journal of Hazardous Materials. 2008 Feb;150(3): 765-73. <DOI .

26. Liu Y, Gao M, Gu Z, Luo Z, Ye Y, Lu L. Comparison between the removal of phenol and catechol by modified montmorillonite with two novel hydroxyl-containing Gemini surfactants. Journal of Hazardous Materials. 2014 Feb;267:7180. $\leq \mathrm{DOI}>$.

27. Hassen JH. Montmorillonite Nanoclay Interaction with 2-Aminophenol and 2-Nitrophenol. Rese Jour of Pharm and Technol. 2019;12(6):2828. <DOI>.

28. Eltantawy IM, Arnold PW. Reappraisal Of Ethylene Glycol Mono-Ethyl Ether (Egme) Method For Surface Area Estimations Of Clays. Journal of Soil Science. 1973 Jun;24(2):232-8. <DOI>.

29. Solomon DH, Loft BC, Swift JD. Reactions catalysed by minerals. IV. The mechanism of the benzidine blue reaction on silicate minerals. Clay miner. 1968 Dec;7(4):389-97.

30. Rozenson I. Reduction and Oxidation of Fe3+ in Dioctahedral Smectites-1: Reduction with Hydrazine and Dithionite. Clays and Clay Minerals. $1976 ; 24(6): 271-82$. <DOI $>$.

31. Sofen SR, Ware DC, Cooper SR, Raymond KN. Structural, electrochemical, and magnetic properties of a four-membered redox series ( $[\mathrm{Cr}(\mathrm{L} 3)] \mathrm{n}-, \mathrm{n}=0-3)$ in catechol-benzoquinone complexes of chromium. Inorg Chem. 1979 Feb $1 ; 18(2): 234-9$. $\leq \mathrm{DOI}>$.

32. Isaacson PJ, Sawhney BL. Sorption and transformation of phenols on clay surfaces: effect of exchangeable cations. Clay miner. 1983 Sep; 18(3):253-65. <DOI .

33. Greene-Kelly R. The Montmorillonite Minerals (Smectites). In: Mackenzie $\mathrm{R}$, editor. The Differential Thermal Investigation of Clay. London: Mineralogical Society; 1957. p. 140-64.

34. Goodman BA. An investigation by Mössbauer and EPR spectroscopy of the possible presence of iron-rich impurity phases in some montmorillonites. Clay miner. 1978 Sep;13(3):351-6. <DOI>.

35. Pinnavaia TJ, Hall PL, Cady SS, Mortland MM. Aromatic radical cation formation on the intracrystal surfaces of transition metal layer lattice silicates. J Phys Chem. 1974 May; 78(10): 994-9. <DOl>.
36. Rozenson I. Reduction and Oxidation of Fe3+ in Dioctahedral Smectites-III.* Oxidation of Octahedral Iron in Montmorillonite. Clays and Clay Minerals. 1978;26(2):88-92. <DOI .

37. Holtzer M, Bobrowski A, Grabowska B. Montmorillonite: a comparison of methods for its determination in foundry bentonites. Metalurgija. 2011;50(2):119-22.

38. Dyal RS, Hendricks SB. Total surface of clays in polar liquids as a characteristic index: soil science. 1950 Jun;69(6):503-9. <DOI>. 
